\title{
Klasifikasi Kematangan Stroberi Berbasis Segmentasi Warna dengan Metode HSV
}

\author{
Indrabayu $^{1 *}$, Nurhikma Arifin ${ }^{1}$, Intan Sari Areni ${ }^{2}$ \\ ${ }^{1}$ Departemen Teknik Informatika, Fakultas Teknik, Universitas Hasanuddin \\ ${ }^{2}$ Departemen Teknik Elektro, Fakultas Teknik, Universitas Hasanuddin \\ Jl. Poros Malino km. 6, Bontomarannu, Kabupaten Gowa, Sulawesi Selatan 92171 \\ *Email: indrabayu@unhas.ac.id
}

DOI: 10.25042/jpe.112019.03

\begin{abstract}
Abstrak
Klasifikasi kematangan buah secara manual memiliki banyak keterbatasan karena dipengaruhi faktor subjektivitas manusia sehingga pengaplikasian pengolahan citra digital dan kecerdasaan buatan menjadi lebih efektif dan efisien. Penelitian ini bertujuan untuk membuat sistem klasifikasi kematangan buah stoberi secara otomatis yang dibagi menjadi tiga kategori, yaitu belum matang, setengah matang, dan matang. Proses identifikasi tingkat kematangan buah pada penelitian ini didasarkan pada ciri warna yaitu mengambil nilai Red, Green, Blue (RGB) dari citra. Adapun metode yang digunakan untuk segmentasi warna adalah Hue, Saturation, Value (HSV) dan untuk klasifikasi kematangan stroberi menggunakan algoritma Multi-Class Support Vector Machine (SVM) dengan kernel Radial Basic Function (RBF). Pengambilan data stroberi menggunakan kamera Logitech C920. Dataset yang digunakan terdiri dari 158 gambar stroberi. Hasil penelitian menunjukkan bahwa klasifikasi kematangan stroberi menggunakan algoritma multiclass SVM dengan parameter kernel RBF cost $(C)=10$ dan gamma $(\gamma)=10^{-3}$ menghasilkan akurasi tertinggi yaitu $97 \%$.
\end{abstract}

\begin{abstract}
Classification of Strawberry Maturity Based on Color Segmentation using HSV Method. Manual fruit maturity classification has many limitations because it is influenced by human subjectivity. Hence, the application of digital image processing and artificial intelligence becomes more effective and efficient. This study aims to create a classification system that automatically divides strawberry maturity into three categories, namely not ripe, half-ripe, and ripe. The process of identifying the level of fruit maturity is based on the color characteristics Red, Green, Blue (RGB) value of the image. The method used for color segmentation is Hue, Saturation, Value (HSV) and for the classification of strawberry maturity using the Multi-Class Support Vector Machine (SVM) algorithm with a Radial Basic Function (RBF) kernel. Strawberry image data was retrieved using the Logitech C920 camera. The dataset consisted of 158 images of strawberries. The results showed that the classification of strawberry maturity using the multi-class SVM algorithm with kernel parameters RBF cost $(C)=10$ and gamma $(\gamma)=10^{-3}$ produced the highest accuracy of $97 \%$.
\end{abstract}

Kata Kunci: Pengolahan citra, HSV, stroberi, SVM

\section{Latar Belakang}

Stroberi merupakan buah yang disukai oleh konsumen dan bernilai jual tinggi. Buah stroberi dapat dikonsumsi segar atau dalam bentuk olahan seperti sirup, selai, dodol, manisan dan bahan tambahan pada kue atau es. Kondisi buah stroberi ditentukan oleh beberapa parameter. Salah satunya adalah parameter tingkat kematangan buah yang bisa dilihat dari perubahan warna buah stroberi [1].

Namun, pada proses klasifikasi kematangan stroberi yang dilakukan secara manual memiliki banyak keterbatasan karena dipengaruhi subjektivitas manusia seperti cepat lelah dan pengaruh fisik lainnya, sehingga pada kondisi tertentu proses pengklasifikasian tidak konsisten. Klasifikasi yang tidak konsisten akan berpengaruh terhadap kualitas buah yang akan dipasarkan baik secara langsung maupun yang akan diolah menjadi produk. Oleh karena itu solusi dari masalah tersebut adalah sistem yang mampu melakukan klasifikasi kematangan stroberi secara konsisten dan akurat, sehingga dapat meminimalisir kesalahan yang dilakukan oleh manusia.

Teknologi pertanian yang semakin canggih mampu menggantikan peran manusia, seperti pemanfaatan pengolahan citra digital yang merupakan bagian dari perkembangan teknologi sehingga mesin komputer dapat mengenali citra seperti layaknya manusia, khususnya dalam mengenali tingkat kematangan buah. Terdapat 
banyak penelitian yang dilakukan dalam melakukan penilaian kualitas dan kematangan buah tersebut secara otomatis. Ananto dkk. [2] pada tahun 2015 membuat aplikasi pengolahan citra untuk mendeteksi kualitas cabai berdasarkan tingkat kematangan menggunakan tranformasi warna YcbCr. Berdasarkan input pelatihan deteksi jenis warna kulit cabai diperoleh dari pengolahan citra dengan metode transformasi warna YCbCr. Dari hasil penelitian 30 sampel buah dari 10 buah pada masingmasing kondisi cabai yaitu, mentah, setengah matang, dan matang dengan dihitung nilai ratarata maksimal dan minimal $\mathrm{cb}$ dan $\mathrm{cr}$ diperoleh akurasi $96 \%$.

Penelitian yang sama juga dilakukan oleh Indarto dkk. [3] pada tahun 2017 mendeteksi kematangan buah pisang berdasarkan fitur warna citra kulit pisang. Data yang digunakan berupa citra pisang dengan mengambil fitur warna yaitu nilai RGB yang kemudian diubah ke Hue, Saturation, dan Intensitas (HSI) dengan akurasi $85 \%$.

Selain itu Li dkk. [4] juga melakukan penelitian untuk mengenali stroberi yang matang langsung pada pohonnya dengan metode deep learning. Sistem ini untuk membantu mesin dalam memisahkan buah stroberi dari daun dan stroberi yang saling tumpang tindih. Penelitian ini menggunakan dua metode pada tahap pengenalan buah stroberi yang matang untuk dibandingkan yaitu CaffeNet dan SVM. Hasil menunjukkan bahwa pengenalan stroberi matang menggunakan metode Caffe-Net memiliki akurasi lebih baik $11 \%$ dari SVM yaitu akurasi masing-masing $95 \%$ dan $84 \%$.

Berdasarkan studi literatur sebelumnya, pengolahan citra mampu mengatasi masalah dalam menangani klasifikasi kematangan buah. Sehingga pada penelitian ini akan menerapkan sistem klasifikasi tingkat kematangan buah dengan memanfaatkan pengolahan citra digital dan kecerdasan buatan dengan menggunakan standar yang sama, sehingga sistem ini melakukan klasifikasi kematangan stroberi secara konsisten dan akurat. sistem ini mengklasifikasikan kematangan stroberi menjadi 3 kategori kelas yaitu stroberi belum matang, setengah matang, dan matang. Namun pada sistem ini diimplementasikan pengolahan citra digital dengan metode Hue, Saturation, dan Value (HSV) pada proses segmentasi sehingga memudahkan dalam pemisahan background dan objek stroberi dari berbagai ukuran dan bentuk. Proses segmentasi HSV didasarkan pada ciri warna stroberi dengan mengambil nilai Red, Green, dan Blue (RGB) pada citra. Sedangkan untuk klasifikasi menggunakan algoritma Support Vector Machine (SVM). Salah satu penelitian yang telah menggunakan metode SVM ini dilakukan oleh Ismail dkk. [5] untuk mendeteksi pelat nomor kendaraan.

\section{Sumber Data}

Dataset yang digunakan pada penelitian ini terdiri dari stroberi belum matang, setengah matang dan matang dengan total data 158 gambar stroberi. Dataset ini dibagi kedalam dua jenis data yaitu data latih dan data uji. Data latih yang akan digunakan sebanyak $80 \%$ dari total data. Data ini berupa data stroberi yang terlebih dahulu diproses untuk membentuk pola atau fitur yang akan digunakan dalam proses data uji. Sedangkan data uji yang digunakan sebanyak 20\% dari total data. Data ini yang akan diproses dan dicocokkan dengan pola atau fitur hasil proses training dari data latih. Adapun pengambilan data pada penelitian ini dilakukan dengan menggunakan kamera Logitech C920 dengan resolusi 1920 x 1080 piksel, 15 megapixel snapshot dan bitrate 30 Fps. Kamera dipasang di dalam box ukuran $25 \times 15 \mathrm{~cm}$ dengan kondisi pencahayaan yang telah ditentukan, yaitu menggunakan LED strip dan jarak antara kamera dengan objek stroberi adalah $25 \mathrm{~cm}$. Data stroberi kemudian diolah menggunakan bahasa pemrograman python. Contoh data latih yang digunakan ditunjukkan pada Gambar 1.

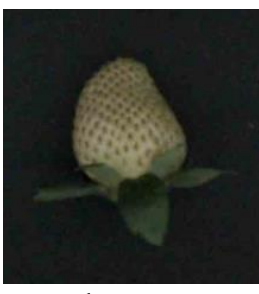

a. Belum matang

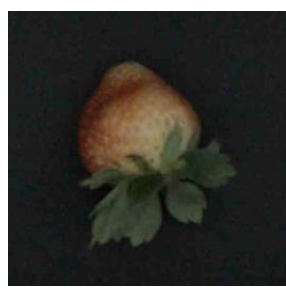

b. Setengah matang

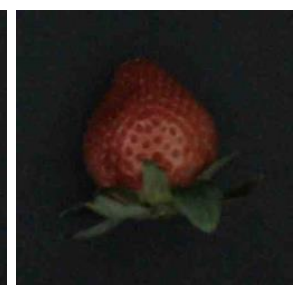

c. Matang
Gambar 1. Contoh data latih

\section{Segmentasi Warna Menggunakan HSV}

Segmentasi warna merupakan proses segmentasi dengan pendekatan daerah yang bekerja dengan menganalisis nilai warna dari tiap piksel pada citra dan membagi citra tersebut 
sesuai dengan fitur yang diinginkan. Salah satu metode segmentasi warna adalah HSV. Segmentasi dengan deteksi HSV dilakukan dengan menganalisis nilai warna tiap piksel citra sesuai fitur yang diinginkan dengan nilai toleransi pada setiap dimensi warna HSV. Ruang warna HSV terdiri dari 3 komponen, yaitu: $\mathrm{H}$ menunjukkan jenis warna (seperti merah, biru atau kuning) atau corak warna, yaitu tempat warna tersebut ditemukan dalam spektrum warna. S mewakili tingkat dominasi warna yaitu ukuran seberapa besar kemurnian dari warna tersebut. $\mathrm{V}$ mewakili tingkat kecerahan yaitu ukuran seberapa besar kecerahan suatu warna atau seberapa besar cahaya datang dari suatu warna [6].

Pada penelitian ini data citra yang tertangkap oleh kamera memiliki warna $R, G$, dan B. Untuk mengurangi efek iluminasi pada sebuah citra, warna citra tersebut dapat dikonversikan ke colour space yang lain, salah satunya adalah ruang warna HSV. Untuk mentransformasi dari RGB ke HSV, perlu diketahui terlebih dahulu nilai max dan min tiap warna, dimana max adalah nilai maksimum dari nilai RGB dan min adalah nilai minimum dari nilai RGB [7]. Nilai-nilai ini dapat diperoleh menggunakan rumus seperti berikut:

$$
\begin{aligned}
& C \max =\max (R, G, B) \\
& C \min =\min (R, G, B) \\
& C=C \max -C \min
\end{aligned}
$$

Setelah memperoleh nilai $\min$ dan $\max$ untuk tiap warna, maka nilai $\mathrm{H}, \mathrm{S}$, dan $\mathrm{V}$ dapat dicari menggunakan persamaan berikut:

$$
\begin{gathered}
H=\left\{\begin{array}{ll}
60\left(\frac{G-B}{C}\right), & \text { if } C \max =R \\
120+60\left(\frac{B-R}{C}\right), & \text { if } C \max =G \\
240+60\left(\frac{R-G}{C}\right), & \text { if } C \max =B
\end{array}\right\} \\
S=\left\{\begin{array}{ll}
0, & \text { Cmax }=0 \\
\frac{C}{C \max }, & \text { Cmax } \neq 0
\end{array}\right\}
\end{gathered}
$$

Contoh hasil konversi RGB ke HSV ditunjukkan pada Gambar 2 berikut.

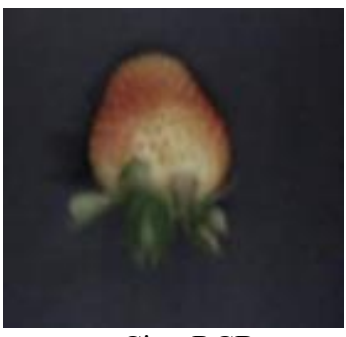

a. Citra RGB

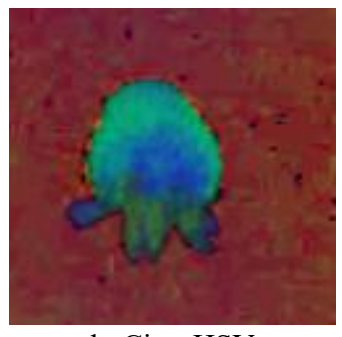

b. Citra HSV
Gambar 2. Hasil konversi RGB ke HSV

Setelah citra HSV diperoleh, maka proses selanjutnya adalah mengubah citra HSV ke citra hitam putih melalui proses masking. Masking adalah proses mengubah suatu citra menjadi citra hitam putih. Proses masking bertujuan untuk memisahkan antara foreground dan background citra dengan memanfaatkan proses thresholding. Proses thresholding menggunakan nilai batas tertentu (threshold) untuk mengubah nilai piksel pada gambar asli menjadi gambar biner, dimana nilai piksel foreground akan bernilai 1 dan nilai piksel background bernilai 0 . Berdasarkan hasil eksperimen yang dilakukan pada kondisi stroberi belum matang, setengah matang, dan matang maka nilai lower dan upper yang optimal dari HSV ditunjukkan pada Tabel 1 berikut:

Tabel 1. Range nilai HSV optimal

\begin{tabular}{cccc}
\hline Value & H & S & V \\
\hline Minimal & 0 & 48 & 33 \\
Maksimal & 77 & 255 & 212 \\
\hline
\end{tabular}

Setelah proses masking selanjutnya menganalisis luas area objek pada citra untuk dilakukan bounding box. Blob detection akan menganalisis luas area dan bentuk objek blob dari suatu citra yang menjadi fokus deteksi. Hasil find contour ditunjukkan pada Gambar 3 berikut:

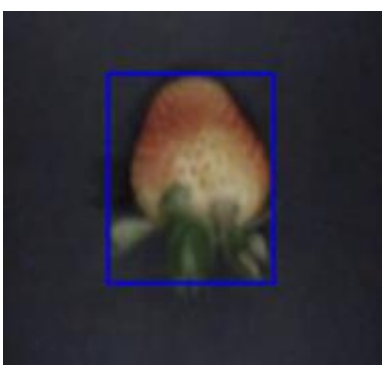

a. Bounding box

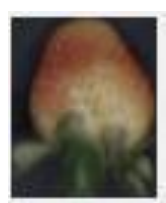

b. Hasil crop
Gambar 3. bounding box dan hasil crop 
Selanjutnya dilakukan ekstraksi fitur dengan mengambil nilai rata-rata dari $\mathrm{R}, \mathrm{G}$, dan $\mathrm{B}$ pada citra sebagai pembeda antar objek.

\section{Klasifikasi Menggunakan Algoritma SVM}

SVM adalah algoritma penyelesaian masalah pengklasifikasian dengan mencari pemisah hyperplane yang optimal antar kelas. Hyperplane bergantung dari kasus pelatihan yang meletakkannya pada tepi dari deskriptor kelas yang disebut support vector. Prinsip dasar SVM adalah linear classifier, dan selanjutnya dikembangkan agar dapat bekerja pada masalah non-linear, dengan memasukkan konsep kernel trick pada ruang kerja berdimensi tinggi. Algoritma SVM memiliki 4 kernel function yaitu kernel linear, Radial Basic Function (RBF), sigmoid dan polynomial. Metode klasifikasi yang digunakan pada penelitian ini menggunakan kernel RBF. Proses training dilakukan dengan mencari nilai optimal dari parameter RBF yaitu $C$ dan Gamma. Nilai optimal dari $C=10$ dan Gamma $=10^{-3}$. Output dari proses training adalah alpha $(\alpha)$ dan nilai bias yang akan digunakan untuk proses uji.

\section{Kesimpulan}

Klasifikasi kematangan stroberi menghasilkan akurasi sebesar 97\% dengan kernel RBF. Kematangan stroberi dapat diimplementasikan menggunakan Image processing. Pada tahap segmentasi prototype sistem klasifikasi kematangan buah stroberi menggunakan metode HSV. Proses ini menghasilkan nilai optimal lower $\mathrm{HSV}=$ $(0,48,33)$ dan upper HSV $=(77,255,212)$. Nilai tersebut dapat memisahkan objek stroberi dengan background secara tepat meskipun warna pada setiap kategori kelas berbeda.

\section{Referensi}

[1] Indrianto, O.H., Supriyanto, C., n.d. Klasifikasi Kematangan Buah Strawberry menggunaka Algoritma K-MEANS 12.

[2] D Ananto, I.D., 2015. Aplikasi Pengolahan Citra Mendeteksi Kualitas Cabai berdasarkan Tingkat Kematangan menggunakan Transformasi Warna YCbCr 3, 11 .

[3] Indarto, Murinto, 2017. Deteksi Kematangan Buah Pisang Berdasarkan Fitur Warna Citra Kulit Pisang Menggunakan Metode Transformasi Ruang Warna HIS (Banana Fruit Detection Based on Banana Skin Image Features Using HSI Color Space Transformation Method) V.

[4] Li, X., Li, J., Tang, J., 2018. A deep learning method for recognizing elevated mature strawberries, in: 2018 33rd Youth Academic Annual Conference of Chinese Association of Automation (YAC). Presented at the 2018 33rd Youth Academic Annual Conference of Chinese Association of Automation (YAC), pp. 1072-1077.

[5] Ismail, M., Indrabayu, I., \& Areni, I. S. 2018. Support Vector Machine Method to Reduce the Execution Time of Vehicle Plate Recognition System. EPI International Journal of Engineering, 1(1), pp. 69-75.

[6] Ericks Rachmat Swedia, Margi Cahyanti. 2010. "Algoritma Transformasi Ruang Warna".

[7] R. D. Kusumanto, Alan Novi Tompunu, Wahyu Setyo Pambudi. 2011. "Klasifikasi Warna Menggunakan Pengolahan Model Warna HSV". Jurnal Ilmiah Elite Elektro, Vol. 2, No. 2. 